\title{
EULER-MACLAURIN FORMULAE
}

\author{
LJ. Dedić, M. Matić AND J. PEČARIĆ
}

Abstract. A number of inequalities, for functions whose derivatives are either functions of bounded variation or Lipschitzian functions or functions in $L_{p}$-spaces, is proved by applying the Euler-Maclaurin formulae. The results are applied to obtain some error estimates for the Maclaurin quadrature rules.

Mathematics subject classification (2000): 26D15, 26D20, 26 D99.

Key words and phrases: Euler-Maclaurin formulae, quadrature formulae, functions of bounded variation, Lipschitzian functions.

\section{REFERENCES}

[1] M. Abramowitz AND I. A. Stegun (EDS), Handbook of mathematical functions with formulae, graphs and mathematical tables. National Bureau of Standards, Applied Math. Series 55, 4th printing, Washington, 1965.

[2] I. S. BEREZIN AND N. P. ZhidKOV, Computing methods, Vol. I, Pergamon Press, Oxford, 1965.

[3] P. J. DAVIS AND P. RABINOWITZ, Methods of Numerical Integration, New York, 1975.

[4] LJ. DEDIĆ, M. MATIĆ AND J. PEČARIĆ, On generalizations of Ostrowski inequality via some Euler-type identities, Math. Inequal. Appl., Vol. 3, No. 3 (2000), 337-353.

[5] Lu. Dedić, M. Matić AND J. PEČARIĆ, Some inequalities of Euler-Grüss type, Computers and Mathematics with Applications, 41(2001), 843-856.

[6] S. S. DRAGOMIR, On Simpson's quadrature formula for Lipschitzian mappings and applications, Soochow J. Math, 25(2)(1999), 175-180.

[7] S. S. DRAGOMIR, On Simpson's quadrature formula for mappings of bounded variation and applications, Tamkang J. Math. 30, No. 1 (1999), 53-58.

[8] S. S. DRAGOMIR, On Simpson's quadrature formula for differentiable mappings whose derivatives belong to $L_{p}$ spaces and applications, J. KSIAM, 22(1998), 57-65.

[9] S. S. Dragomir, R. P. Agarwal and P. Cerone, On Simpson's inequality and applications, J. of Inequal. \& Appl., 5(6)(2000), 533-579.

[10] F. B. HildebRAND, Introduction to Numerical Analysis, New York, 1956.

[11] V. I. KRYLOV, Approximate calculation of integrals, Macmillan, New York-London, 1962.

[12] D. S. Mitrinović, J. E. PEČARIĆ AND A. M. FINK, Inequalities Involving Functions and Their Integrals and Derivatives, Kluwer Academic Publishers, Dordrecht, 1991.

[13] C. E. M. PEARCE, J. PEČARIĆ, N. UJEVIĆ AND S. VAROŠANEC, Generalizations of some inequalities of Ostrowski-Grü ss type, Math. Inequal. Appl., Vol. 3, No. 1 (2000), 25-34. 